\title{
Gerontology
}

\section{Type 2 Diabetes in Octogenarians Is Associated with Decreased Low Molecular Weight Adiponectin}

\author{
Juergen Graessler ${ }^{a}$ Matthias Gruber ${ }^{a}$ Rolf-Bernd Radke ${ }^{b}$ Steffi Kopprasch ${ }^{a}$ \\ Peter E.H. Schwarz ${ }^{\text {a }}$ Wolfram Kamke ${ }^{c}$ Stefan R. Bornstein ${ }^{a}$ Sabine Fischer ${ }^{a}$ \\ a Department of Internal Medicine III, Carl Gustav Carus Medical School, University of Technology, Dresden, \\ ${ }^{\mathrm{b}}$ Rehabilitation Hospital Wolletzsee, Angermünde, and ${ }^{\mathrm{C}}$ Rehabilitation Hospital Spreewaldklinik, Burg, Germany
}

\section{Key Words}

Adiponectin • Diabetes mellitus • Octogenarians

\begin{abstract}
Background: Adiponectin circulates in the blood in three different multimer isoforms, of which the high molecular weight form (HMW) is presumed to mediate insulin sensitivity. We examined whether adiponectin oligomer distribution is associated with aging and type 2 diabetes (T2D) in octogenarians without characteristic features of metabolic syndrome. Methods: The study included 154 octogenarians (58 men, 96 women), 24 normoglycemic middle-aged controls ( 11 men, 13 women; mean age 44 years), and 33 middleaged individuals (14 men, 19 women; mean age 55 years) with T2D. Based on oral glucose tolerance test 62 octogenarians had normal, 63 impaired glucose tolerance, and 29 octogenarians had newly detected T2D. Serum adiponectin multimer isoforms were measured after overnight fast by enzyme-linked immunosorbent assays. Results: Compared to the normoglycemic middle-aged control group, male normoglycemic octogenarians revealed significantly higher total adiponectin and all adiponectin isoforms. The same was true for females with the exception of low molecular weight (LMW) adiponectin, which was not statistically higher in octogenarians. Male and female octogenarians with T2D had significantly higher levels of total, HMW, and middle molecu-
\end{abstract}

lar weight (MMW) adiponectin, but not LMW adiponectin, than middle-aged individuals with T2D. Female, but not male, octogenarians revealed significantly lower total adiponectin than normoglycemic octogenarians. Compared with normoglycemic octogenarians, male and female octogenarians with T2D were characterized by significantly lower LMW adiponectin. In male and female octogenarians, total adiponectin and all multimer isoforms were directly correlated with HDL cholesterol. LMW adiponectin in octogenarians of both sexes was inversely correlated with glucose level at 2-hour oral glucose tolerance test. Conclusions: Serum levels of total adiponectin as well as its HMW and MMW isoforms were significantly higher in octogenarians with normoglycemia or T2D than in corresponding middle-aged control groups. In male and female octogenarians without metabolic syndrome, T2D was associated with lower LMW adiponectin, while the HMW and MMW isoforms were not statistically different.

Copyright $\odot 2010$ S. Karger AG, Basel

\section{Introduction}

With aging, there is an increased prevalence of insulin resistance and type 2 diabetes (T2D) resulting in a high risk for cardiovascular disease. However, humans over 80 years old are often spared age-related cardiovascular dis-

\section{KARGER}

Fax +4161306 1234

E-Mail karger@karger.ch

www.karger.com
(C) 2010 S. Karger AG, Basel

0304-324X/11/0574-0316\$38.00/0

Accessible online at:

www.karger.com/ger
Prof. Juergen Graessler, MD, Department of Internal Medicine III

Division of Pathological Biochemistry, Carl Gustav Carus Medical School

University of Technology, Fetscherstrasse 74, DE-01307 Dresden (Germany)

Tel. +49 351458 3230, Fax +49351 4585330

E-Mail Juergen.Graessler@ uniklinikum-dresden.de 
eases, probably, in part, due to the preservation of their insulin sensitivity [1]. There is growing evidence that the adipocyte-derived hormone adiponectin plays a protective role against insulin resistance [2], atherosclerosis [3], and aging [4]. Adiponectin exerts its favorable effects on insulin sensitivity in vivo through an activation of $5^{\prime}$ AMP-activated protein kinase (AMPK) in skeletal muscle and liver [5]. Activated AMPK increases fatty acid oxidation and glucose uptake in myocytes and decreases hepatic glucose production by reduced expression of molecules involved in gluconeogenesis in the liver $[5,6]$.

Adiponectin circulates in the blood in three different isoforms: low molecular weight (LMW) trimers (about 67 $\mathrm{kDa}$ ), middle molecular weight (MMW) hexamers (about $136 \mathrm{kDa}$ ), and high molecular weight (HMW) multimers (>300 kDa) [7-9]. Furthermore, globular adiponectin, a proteolytic cleavage product of adiponectin, is also present in human plasma [6]. Concentrations of HMW and MMW isoforms are significantly higher in women than in men [10], while no gender differences have been found for the LMW form [11]. Similarly to total adiponectin, HMW adiponectin has been shown to correlate directly with HDL cholesterol and inversely with triglycerides, insulin sensitivity, and inflammatory markers in T2D patients [10].

Experimental and clinical data suggest that the oligomeric complex distribution of adiponectin is essential for its anti-diabetic and anti-atherogenic activity $[12,13]$, and changes in the relative abundance of each oligomeric isoform in plasma may determine adiponectin activity. In subjects with metabolic syndrome, plasma levels of HMW adiponectin and the HMW to total adiponectin ratio were more effective in the prediction of insulin resistance than total adiponectin level [14]. The improvement of insulin sensitivity by thiazolidinedione treatment was rather associated with increased levels of serum HMW than total adiponectin [7]. In contrast to HMW adiponectin, the role of LMW adiponectin in the pathogenesis of T2D and insulin resistance is less defined. On the one hand, plasma LMW adiponectin was lower in obese individuals and in patients with T2D [15]. It was negatively correlated with waist circumference, body mass index (BMI) and waist-to-hip ratio (WHR) [15]. On the other hand, LMW adiponectin, like HMW and MMW adiponectin, was directly correlated with HDL cholesterol [16]. Based on this strong correlation, HDL cholesterol may account for some of the anti-diabetic and anti-atherogenic actions that have been attributed to adiponectin so far. However, there are several studies reporting biological actions of LMW adiponectin exceeding presumed effects of $\mathrm{HDL}$ cholesterol. Thus, LMW adiponectin specifically reduced monocytic IL- 6 secretion in vitro $[15,17]$. This in turn might attenuate obesity-induced systemic inflammation in vivo.

Apart from insulin sensitization of peripheral tissues, adiponectin has been shown to exert significant effects on energy homeostasis via central mechanisms. Treatment of mice with intracerebroventricular injections of adiponectin resulted in decreased body weight and fat content mediated by hypothalamic AdipoR1 receptors $[18,19]$. The total adiponectin concentration in human cerebrospinal fluid approximates $0.1 \%$ of the plasma concentration [20,21], but LMW adiponectin is the predominant adiponectin isoform in cerebrospinal fluid [20, 21]. Thus, LMW adiponectin through its central action may exert a much higher biological significance than is currently acknowledged.

The present study aimed to characterize the metabolic state of a group of octogenarians by an oral glucose tolerance test (OGTT) and to elucidate the interrelated effects of aging, sex, and insulin resistance on plasma adiponectin isoform distribution.

\section{Research Design and Methods}

Study Population

One hundred and fifty-four octogenarians (58 men, age 82.9 \pm 3.8 years; 96 women, age $83.2 \pm 4.3$ years) without a personal or family history of T2D among first-degree relatives were enrolled at the Spreewaldklinik Rehabilitation Hospital, Burg (Spreewald), Germany. The study was performed in accordance with the Declaration of Helsinki and approved by the local Ethics Committee. Written informed consent was obtained from every subject. Patients with known T2D, plasma LDL cholesterol $\geq 4.5$ $\mathrm{mM}$, triglycerides $\geq 2.6 \mathrm{mM}$, heart failure and severe chronic diseases, as well as postoperative status were excluded from the study.

For comparison, 24 normoglycemic middle-aged control individuals (aged $44 \pm 7$ years, 11 men, 13 women) and 33 middleaged individuals with T2D (aged $55 \pm 8$ years, 14 men, 19 women) were recruited.

All individuals underwent a standardized clinical examination, and current medication was recorded. Blood samples were taken after 12-hour overnight fast for routine laboratory analyses. Subsequently, a standard 75 g OGTT was performed. During OGTT, plasma levels of glucose, insulin, C-peptide, proinsulin and free fatty acids were determined at $0,30,60,90$, and $120 \mathrm{~min}$. Serum samples for adiponectin and hormone measurements were prepared immediately, shock frozen in liquid nitrogen and stored at $-80^{\circ} \mathrm{C}$ until analysis. Impaired glucose tolerance (IGT) and T2D were diagnosed according to the ADA and World Health Organization criteria [22]. Normal glucose tolerance (NGT) was diagnosed in 62 (24 men, 38 women), IGT in 63 (24 men, 39 women) octogenarians. T2D was newly diagnosed in 29 (10 men, 19 
women) octogenarians, which represented $18.8 \%$ of the investigated octogenarian population.

According to Matthews' [23] 'homeostasis model assessment of insulin resistance' (HOMA-IR) as an index for insulin resistance was calculated by the formula: (fasting insulin $[\mu \mathrm{U} / \mathrm{ml}] \times$ fasting glucose $[\mathrm{mM}]) / 22.5$.

\section{Laboratory Analyses}

Plasma triglycerides, total cholesterol, HDL, and LDL cholesterol were determined by standard methods on a modular analyzer (Roche, Indianapolis, Ind., USA), free fatty acids on a Cobas Mira analyzer (Global Medical Instrumentation, Inc., Ramsey, Minn., USA), and plasma glucose on a DX80 analyzer (BeckmanCoulter, Fullerton, Calif., USA). $\mathrm{HbA}_{1 \mathrm{C}}$ was measured by fully automated HPLC system (Bio-Rad Laboratories, Richmond, Calif., USA). Plasma levels of insulin and C-peptide were determined by enzyme-linked immunosorbent assays (ELISA) from BioSource (BioSource Europe SA, Belgium), and proinsulin by an ELISA from DRG Diagnostics (Marburg, Germany).

\section{Assay for Adiponectin Multimer Complexes}

The measurement of adiponectin multimer complexes was performed using the Adiponectin (Multimeric) ELISA from ALPCO Diagnostics (Salem, N.H., USA) for quantitative and selective determinations of HMW, MMW, and total adiponectin in serum. This assay is able to directly quantify total adiponectin, HMW + MMW and HMW. Concentrations of LMW and MMW were obtained by subtracting HMW + MMW from total adiponectin and HMW from HMW + MMW, respectively. The ELISA, which uses two monoclonal antibodies, had a linear range of $0.075-4.8 \mathrm{ng} / \mathrm{ml}$. Intra-assay coefficients of variations for total, HMW + MMW, and HMW adiponectin were reported to be 5.3, 4.1 and $3.3 \%$, respectively. The interassay coefficients of variations were 5.0, 6.0 and 5.7\% for total, HMW + MMW, and HMW adiponectin, respectively. Each of the three forms of adiponectin multimer levels closely correlated with the total adiponectin levels in healthy subjects [11].

\section{Statistics}

Differences of basal anthropometric and clinical data in men and women among multiple groups (octogenarians with NGT, with IGT or type 2 diabetes mellitus, and middle-aged (younger) individuals with NGT or type 2 diabetes mellitus) were analyzed by univariate analysis of variance (ANOVA) and post-hoc Bonferroni tests.

To avoid significant pharmacological effects on study results, specific drug effects were excluded by a separate analysis of variance preceding subsequent statistical evaluation.

Comparisons of serum levels of separate adiponectin isoforms among sex-stratified groups of octogenarians and controls were realized by a univariate model of variance with age and $\mathrm{BMI}$ as covariates (ANCOVA) and post-hoc testing with p values corrected for multiple testing (Bonferroni procedure). Complex interaction of adiponectin isoforms and all groups of investigation was analyzed using a model of multivariate analysis of variance with values adjusted for sex, age and BMI. Group differences were subsequently tested by univariate analysis of variance with $p$ values corrected for multiple testing (Bonferroni procedure).

Partial correlation tests were applied to evaluate the strength of association between total adiponectin and adiponectin iso- forms with clinical data. The correlation has been controlled for BMI. Partial $r$ and two-tailed significance have been indicated.

Data are given as mean with $95 \%$ confidence interval, unless otherwise stated. A value of $p<0.05$ was considered statistically significant. All statistical analyses were performed with the SPSS statistical package (v16.0 for Windows; SPSS, Chicago, Ill., USA).

\section{Results}

\section{Basic Characteristics of the Study Population}

Anthropometric data and baseline metabolic parameters of octogenarians and control subjects are given in tables 1 (men) and 2 (women). Middle-aged individuals with T2D of both sexes displayed characteristic diabetesassociated changes in comparison to middle-aged normoglycemic controls, like higher values for BMI, systolic blood pressure, $\mathrm{HbA}_{1 \mathrm{c}}$, HOMA-IR and plasma triglycerides (tables 1, 2). In contrast, these parameters were not significantly different between octogenarians with T2D and octogenarians with NGT of both sexes. These data led to the suggestion that although octogenarians with T2D fulfill the classification criteria for diabetes mellitus, based on fasting blood glucose and 2-hour postchallenge glucose level, they represent a specific pathogenetic entity. In order to proof this assumption, the time course of insulin, C-peptide, and proinsulin during OGTT have been analyzed. In octogenarian men with T2D, an attenuated increase in insulin at 30 min OGTT indicated a delayed response to glucose challenge (fig. 1). In contrast to middle-aged individuals with T2D, in whom maximum insulin level was observed 90 min after glucose load, the insulin level in octogenarians with T2D increased until the end of the observation period (fig. 1). In accordance, comparable kinetics could be demonstrated for C-peptide curves (online suppl. table A, www. karger.com/doi/10.1159/000316575). In middle-aged individuals with $\mathrm{T} 2 \mathrm{D}$, the level of proinsulin reached a maximum also at 90 min OGTT, which remained unchanged up to $120 \mathrm{~min}$ (online suppl. table B). The absolute values of proinsulin at $90 \mathrm{~min}$ in octogenarians with T2D tended to be lower, but increased further until 120 min (online suppl. table B). Statistically significant differences of proinsulin/insulin ratios during OGTT between octogenarians and middle-aged controls with T2D could not be established (online suppl. table C).

Taken together, these observations underline the specificity of the investigated octogenarian population. In particular, octogenarians with T2D do not reveal obvious characteristics of the metabolic syndrome or beta-cell insufficiency. It is suggested that a combination of reduced 
Table 1. Basal anthropometric and clinical data of male octogenarians with NGT (NGT-Oc), IGT (IGT-Oc), and type 2 diabetes mellitus (T2D-Oc), and of middle-aged (younger) male normoglycemic controls (NGT-Y) and individuals with type 2 diabetes (T2D-Y)

\begin{tabular}{|c|c|c|c|c|c|c|c|}
\hline & & $\begin{array}{l}\text { NGT-Oc } \\
(\mathrm{n}=24)\end{array}$ & $\begin{array}{l}\text { IGT-Oc } \\
(\mathrm{n}=24)\end{array}$ & $\begin{array}{l}\text { T2D-Oc } \\
(\mathrm{n}=10)\end{array}$ & $\begin{array}{l}\text { NGT-Y } \\
(\mathrm{n}=11)\end{array}$ & $\begin{array}{l}\text { T2D-Y } \\
(\mathrm{n}=14)\end{array}$ & $\mathrm{p}$ \\
\hline Age, years & $\begin{array}{l}\text { mean } \\
95 \% \text { CI }\end{array}$ & $\begin{array}{l}83.0 \\
82.1-84.0\end{array}$ & $\begin{array}{l}83.0 \\
82.2-83.8\end{array}$ & $\begin{array}{l}82.7 \\
81.2-84.3\end{array}$ & $\begin{array}{l}43.3 \\
37.2-49.4\end{array}$ & $\begin{array}{l}55.5 \\
50.9-60.1\end{array}$ & $<0.001^{1,2}$ \\
\hline BMI & $\begin{array}{l}\text { mean } \\
95 \% \mathrm{CI}\end{array}$ & $\begin{array}{l}26.4 \\
25.1-27.7\end{array}$ & $\begin{array}{l}24.0 \\
22.9-25.1\end{array}$ & $\begin{array}{l}26.9 \\
24.1-29.8\end{array}$ & $\begin{array}{l}25.2 \\
24.5-25.9\end{array}$ & $\begin{array}{l}29.4 \\
27.7-31.0\end{array}$ & $<0.001^{3}$ \\
\hline WHR & $\begin{array}{l}\text { mean } \\
95 \% \text { CI }\end{array}$ & $\begin{array}{l}0.95 \\
0.93-0.98\end{array}$ & $\begin{array}{l}0.94 \\
0.92-0.96\end{array}$ & $\begin{array}{l}0.98 \\
0.93-1.03\end{array}$ & $\begin{array}{l}0.91 \\
0.87-0.94\end{array}$ & $\begin{array}{l}0.98 \\
0.96-1.01\end{array}$ & $0.011^{4}$ \\
\hline RR syst., mm Hg & $\begin{array}{l}\text { mean } \\
95 \% \mathrm{CI}\end{array}$ & $\begin{array}{l}135 \\
129-141\end{array}$ & $\begin{array}{l}133 \\
128-138\end{array}$ & $\begin{array}{l}126 \\
116-137\end{array}$ & $\begin{array}{l}127 \\
116-139\end{array}$ & $\begin{array}{l}145 \\
136-155\end{array}$ & $0.007^{5}$ \\
\hline RR diast., $\mathrm{mm} \mathrm{Hg}$ & $\begin{array}{l}\text { mean } \\
95 \% \mathrm{CI}\end{array}$ & $\begin{array}{l}81 \\
77-85\end{array}$ & $\begin{array}{l}78 \\
73-83\end{array}$ & $\begin{array}{l}72 \\
63-80\end{array}$ & $\begin{array}{l}73 \\
67-80\end{array}$ & $\begin{array}{l}84 \\
77-90\end{array}$ & 0.014 \\
\hline $\mathrm{HbA}_{1 \mathrm{c}}, \%$ & $\begin{array}{l}\text { mean } \\
95 \% \mathrm{CI}\end{array}$ & $\begin{array}{l}5.5 \\
5.4-5.7\end{array}$ & $\begin{array}{l}5.4 \\
5.2-5.6\end{array}$ & $\begin{array}{l}5.9 \\
5.5-6.2\end{array}$ & $\begin{array}{l}5.3 \\
5.0-5.6\end{array}$ & $\begin{array}{l}6.2 \\
5.9-6.5\end{array}$ & $<0.001^{3}$ \\
\hline HOMA-IR & $\begin{array}{l}\text { mean } \\
95 \% \mathrm{CI}\end{array}$ & $\begin{array}{l}2.5 \\
2.0-3.0\end{array}$ & $\begin{array}{l}3.3 \\
2.7-3.9\end{array}$ & $\begin{array}{l}3.1 \\
2.1-4.2\end{array}$ & $\begin{array}{l}2.0 \\
1.4-2.6\end{array}$ & $\begin{array}{l}5.3 \\
3.5-7.1\end{array}$ & $<0.001^{2}$ \\
\hline$\overline{\mathrm{TG}}, \mathrm{mM}$ & $\begin{array}{l}\text { mean } \\
95 \% \text { CI }\end{array}$ & $\begin{array}{l}0.96 \\
0.86-1.06\end{array}$ & $\begin{array}{l}1.17 \\
1.01-1.32\end{array}$ & $\begin{array}{l}1.19 \\
0.78-1.60\end{array}$ & $\begin{array}{l}1.41 \\
1.08-1.75\end{array}$ & $\begin{array}{l}2.21 \\
1.19-3.22\end{array}$ & $<0.001^{6}$ \\
\hline Total chol., mM & $\begin{array}{l}\text { mean } \\
95 \% \mathrm{CI}\end{array}$ & $\begin{array}{l}4.30 \\
3.86-4.74\end{array}$ & $\begin{array}{l}4.29 \\
3.74-4.83\end{array}$ & $\begin{array}{l}4.47 \\
3.88-5.06\end{array}$ & $\begin{array}{l}5.32 \\
4.60-6.03\end{array}$ & $\begin{array}{l}5.03 \\
4.45-5.61\end{array}$ & $0.011^{7}$ \\
\hline HDL-C, mM & $\begin{array}{l}\text { mean } \\
95 \% \text { CI }\end{array}$ & $\begin{array}{l}1.31 \\
1.15-1.48\end{array}$ & $\begin{array}{l}1.30 \\
1.01-1.58\end{array}$ & $\begin{array}{l}1.28 \\
1.09-1.48\end{array}$ & $\begin{array}{l}1.57 \\
1.36-1.78\end{array}$ & $\begin{array}{l}1.21 \\
1.09-1.34\end{array}$ & 0.074 \\
\hline LDL-C, mM & $\begin{array}{l}\text { mean } \\
95 \% \mathrm{CI}\end{array}$ & $\begin{array}{l}2.61 \\
2.23-2.98\end{array}$ & $\begin{array}{l}2.50 \\
2.13-2.87\end{array}$ & $\begin{array}{l}2.68 \\
2.07-3.29\end{array}$ & $\begin{array}{l}3.50 \\
2.89-4.10\end{array}$ & $\begin{array}{l}3.13 \\
2.62-3.63\end{array}$ & $0.015^{7}$ \\
\hline FFA, mM & $\begin{array}{l}\text { mean } \\
95 \% \text { CI }\end{array}$ & $\begin{array}{l}0.43 \\
0.32-0.55\end{array}$ & $\begin{array}{l}0.51 \\
0.42-0.60\end{array}$ & $\begin{array}{l}0.66 \\
0.44-0.88\end{array}$ & $\begin{array}{l}0.56 \\
0.29-0.83\end{array}$ & $\begin{array}{l}0.53 \\
0.43-0.63\end{array}$ & 0.173 \\
\hline
\end{tabular}

TG = Plasma triglycerides; FFA = free fatty acids. Group differences tested by univariate analysis of variance; Bonferroni test $\mathrm{p} \leq$ 0.05: ${ }^{1} \mathrm{NGT}-\mathrm{Y}$ vs. all; ${ }^{2} \mathrm{~T} 2 \mathrm{D}-\mathrm{Y}$ vs. all; ${ }^{3} \mathrm{~T} 2 \mathrm{D}-\mathrm{Y}$ vs. NGT-Oc, IGT-Oc, NGT-Y; ${ }^{4} \mathrm{~T} 2 \mathrm{D}-\mathrm{Y}$ vs. NGT-Y; ${ }^{5}$ T2D-Y vs. NGT-Y, T2D-Oc; ${ }^{6}$ T2D-Y vs. NGT-Oc, IGT-Oc, T2D-Oc; ${ }^{7}$ NGT-Y vs. IGT-Oc.

peripheral glucose consumption and moderately altered beta-cell function may result in a diabetic state, which is different from the situation in younger diabetic individuals with obesity and clustered metabolic deteriorations.

\section{Total Serum Adiponectin and Adiponectin Multimer Isoforms}

Effect of Age

In comparison to the middle-aged normoglycemic male control group, serum concentrations of total adiponectin and all adiponectin isoforms were higher in normoglycemic octogenarian men (table 3 ). In octogenarian men, the HMW/total adiponectin ratio was higher (41.7 vs. $36.7 \%)$, the LMW/total adiponectin ratio lower (36.0 vs. $39.1 \%$ ) than in normoglycemic middle-aged men. Male octogenarians with T2D revealed significantly higher serum levels of total adiponectin, HMW adiponectin, and MMW adiponectin than middle-aged men with T2D. LMW adiponectin was not different between these two groups.

Similarly, serum concentrations of all adiponectin isoforms were higher in normoglycemic octogenarian women, with the exception of LMW adiponectin that did not reach significance (table 3). Furthermore, the HMW/total adiponectin ratio was higher (47.5 vs. $43.1 \%)$, the LMW/ total adiponectin ratio was significantly lower in normoglycemic octogenarian women ( 27.8 vs. $36.7 \%, \mathrm{p}=0.014$ ), when compared with normoglycemic middle-aged women. Like in men, female octogenarians with T2D had significantly higher serum levels of total adiponectin, HMW adiponectin, and MMW adiponectin than middle-aged women with T2D (table 3). 
Table 2. Basal anthropometric and clinical data of female NGT-Oc, IGT-Oc, T2D-Oc, NGT-Y and T2D-Y

\begin{tabular}{|c|c|c|c|c|c|c|c|}
\hline & & $\begin{array}{l}\text { NGT-Oc } \\
(\mathrm{n}=38)\end{array}$ & $\begin{array}{l}\text { IGT-Oc } \\
(n=39)\end{array}$ & $\begin{array}{l}\text { T2D-Oc } \\
(n=19)\end{array}$ & $\begin{array}{l}\text { NGT-Y } \\
(\mathrm{n}=13)\end{array}$ & $\begin{array}{l}\text { T2D-Y } \\
(n=19)\end{array}$ & $\mathrm{p}$ \\
\hline Age, years & $\begin{array}{l}\text { mean } \\
95 \% \text { CI }\end{array}$ & $\begin{array}{l}83.3 \\
81.9-84.7\end{array}$ & $\begin{array}{l}83.3 \\
82.2-84.3\end{array}$ & $\begin{array}{l}82.4 \\
80.8-84.0\end{array}$ & $\begin{array}{l}44.3 \\
41.7-46.9\end{array}$ & $\begin{array}{l}54.2 \\
50.2-58.2\end{array}$ & $<0.001^{1,2}$ \\
\hline BMI & $\begin{array}{l}\text { mean } \\
95 \% \text { CI }\end{array}$ & $\begin{array}{l}26.5 \\
25.0-27.9\end{array}$ & $\begin{array}{l}25.4 \\
23.8-26.9\end{array}$ & $\begin{array}{l}28.3 \\
25.5-31.0\end{array}$ & $\begin{array}{l}24.1 \\
22.9-25.3\end{array}$ & $\begin{array}{l}32.0 \\
28.3-35.7\end{array}$ & $<0.001^{3}$ \\
\hline WHR & $\begin{array}{l}\text { mean } \\
95 \% \text { CI }\end{array}$ & $\begin{array}{l}0.91 \\
0.88-0.93\end{array}$ & $\begin{array}{l}0.91 \\
0.89-0.94\end{array}$ & $\begin{array}{l}0.90 \\
0.86-0.93\end{array}$ & $\begin{array}{l}0.85 \\
0.78-0.91\end{array}$ & $\begin{array}{l}0.92 \\
0.89-0.95\end{array}$ & 0.117 \\
\hline RR syst., mm Hg & $\begin{array}{l}\text { mean } \\
95 \% \text { CI }\end{array}$ & $\begin{array}{l}136 \\
132-141\end{array}$ & $\begin{array}{l}140 \\
134-146\end{array}$ & $\begin{array}{l}134 \\
126-142\end{array}$ & $\begin{array}{l}120 \\
109-131\end{array}$ & $\begin{array}{l}140 \\
131-149\end{array}$ & $0.007^{1}$ \\
\hline RR diast., $\mathrm{mm} \mathrm{Hg}$ & $\begin{array}{l}\text { mean } \\
95 \% \text { CI }\end{array}$ & $\begin{array}{l}77 \\
73-80\end{array}$ & $\begin{array}{l}76 \\
72-80\end{array}$ & $\begin{array}{l}81 \\
76-86\end{array}$ & $\begin{array}{l}71 \\
62-80\end{array}$ & $\begin{array}{l}86 \\
80-92\end{array}$ & $0.005^{4}$ \\
\hline $\mathrm{HbA}_{1 \mathrm{c}}, \%$ & $\begin{array}{l}\text { mean } \\
95 \% \text { CI }\end{array}$ & $\begin{array}{l}5.6 \\
5.3-5.9\end{array}$ & $\begin{array}{l}5.4 \\
5.3-5.5\end{array}$ & $\begin{array}{l}6.0 \\
5.7-6.3\end{array}$ & $\begin{array}{l}5.3 \\
5.1-5.4\end{array}$ & $\begin{array}{l}6.2 \\
6.0-6.5\end{array}$ & $<0.001^{3,5}$ \\
\hline HOMA-IR & $\begin{array}{l}\text { mean } \\
95 \% \mathrm{CI}\end{array}$ & $\begin{array}{l}3.0 \\
2.4-3.6\end{array}$ & $\begin{array}{l}3.0 \\
2.5-3.4\end{array}$ & $\begin{array}{l}3.8 \\
3.0-4.6\end{array}$ & $\begin{array}{l}2.2 \\
1.6-2.8\end{array}$ & $\begin{array}{l}6.2 \\
4.7-7.7\end{array}$ & $<0.001^{2}$ \\
\hline $\mathrm{TG}, \mathrm{mM}$ & $\begin{array}{l}\text { mean } \\
95 \% \text { CI }\end{array}$ & $\begin{array}{l}1.22 \\
1.12-1.33\end{array}$ & $\begin{array}{l}1.39 \\
1.21-1.58\end{array}$ & $\begin{array}{l}1.55 \\
1.23-1.88\end{array}$ & $\begin{array}{l}1.01 \\
0.74-1.29\end{array}$ & $\begin{array}{l}1.84 \\
1.29-2.39\end{array}$ & $0.003^{4}$ \\
\hline Total chol., mM & $\begin{array}{l}\text { mean } \\
95 \% \text { CI }\end{array}$ & $\begin{array}{l}5.29 \\
4.99-5.58\end{array}$ & $\begin{array}{l}5.35 \\
5.00-5.71\end{array}$ & $\begin{array}{l}5.02 \\
4.57-5.47\end{array}$ & $\begin{array}{l}5.12 \\
4.64-5.60\end{array}$ & $\begin{array}{l}5.24 \\
4.84-5.64\end{array}$ & 0.847 \\
\hline HDL-C, mM & $\begin{array}{l}\text { mean } \\
95 \% \text { CI }\end{array}$ & $\begin{array}{l}1.49 \\
1.37-1.61\end{array}$ & $\begin{array}{l}1.48 \\
1.35-1.62\end{array}$ & $\begin{array}{l}1.31 \\
1.18-1.44\end{array}$ & $\begin{array}{l}2.15 \\
1.91-2.40\end{array}$ & $\begin{array}{l}1.44 \\
1.24-1.63\end{array}$ & $<0.001^{1}$ \\
\hline LDL-C, mM & $\begin{array}{l}\text { mean } \\
95 \% \mathrm{CI}\end{array}$ & $\begin{array}{l}3.27 \\
3.00-3.54\end{array}$ & $\begin{array}{l}3.28 \\
2.98-3.59\end{array}$ & $\begin{array}{l}3.02 \\
2.64-3.40\end{array}$ & $\begin{array}{l}2.87 \\
2.45-3.29\end{array}$ & $\begin{array}{l}3.20 \\
2.82-3.57\end{array}$ & 0.599 \\
\hline FFA, mM & $\begin{array}{l}\text { mean } \\
95 \% \mathrm{CI}\end{array}$ & $\begin{array}{l}0.61 \\
0.53-0.69\end{array}$ & $\begin{array}{l}0.67 \\
0.59-0.76\end{array}$ & $\begin{array}{l}0.67 \\
0.55-0.79\end{array}$ & $\begin{array}{l}0.54 \\
0.43-0.66\end{array}$ & $\begin{array}{l}0.79 \\
0.67-0.91\end{array}$ & 0.044 \\
\hline
\end{tabular}

Group differences tested by univariate analysis of variance; Bonferroni test $\mathrm{p} \leq 0.05:{ }^{1} \mathrm{NGT}-\mathrm{Y}$ vs. all; ${ }^{2} \mathrm{~T} 2 \mathrm{D}-$ Y vs. all; ${ }^{3}$ T2D-Y vs. NGT-Oc, IGT-Oc, NGT-Y; ${ }^{4}$ T2D-Y vs. NGT-Y; ${ }^{5}$ IGT-Oc vs. T2D-Oc.

Effect of Sex

Women of the octogenarian NGT group had significantly higher total, HMW, and MMW adiponectin than men in the corresponding octogenarian NGT group. Serum LMW adiponectin of both groups was not statistically different (table 3 ). The same tendencies could also be detected in the group of middle-aged individuals with normoglycemia and in the octogenarian IGT group showing significantly higher levels in women of total, HMW, and LMW adiponectin, but no significant differences for MMW multimers.

Significantly higher serum concentrations of total and HMW adiponectin were found in middle-aged women with T2D in comparison to men of the same group. In contrast, no differences could be established between male and female octogenarians with T2D.

\section{Effect of T2D}

Middle-aged men with T2D revealed a tendency of lower total, HMW, and MMW adiponectin, which did not reach statistical significance (table 3). Unlike men, middle-aged women with T2D were characterized by a tendency for lower total and LMW adiponectin. This tendency was enhanced in female octogenarians with T2D, resulting in significantly lower LMW adiponectin. In addition, female octogenarians with $\mathrm{T} 2 \mathrm{D}$ displayed also a tendency of lower HMW adiponectin. Taken together, these changes resulted in significantly lower total adiponectin in female octogenarians with T2D (table 3).

In accordance, significantly lower values for LMW adiponectin could also be observed in male octogenarians with T2D in comparison with the normoglycemic octogenarian group (table 3 ). In contrast to female octogenarians, these changes were not accompanied by lower HMW 


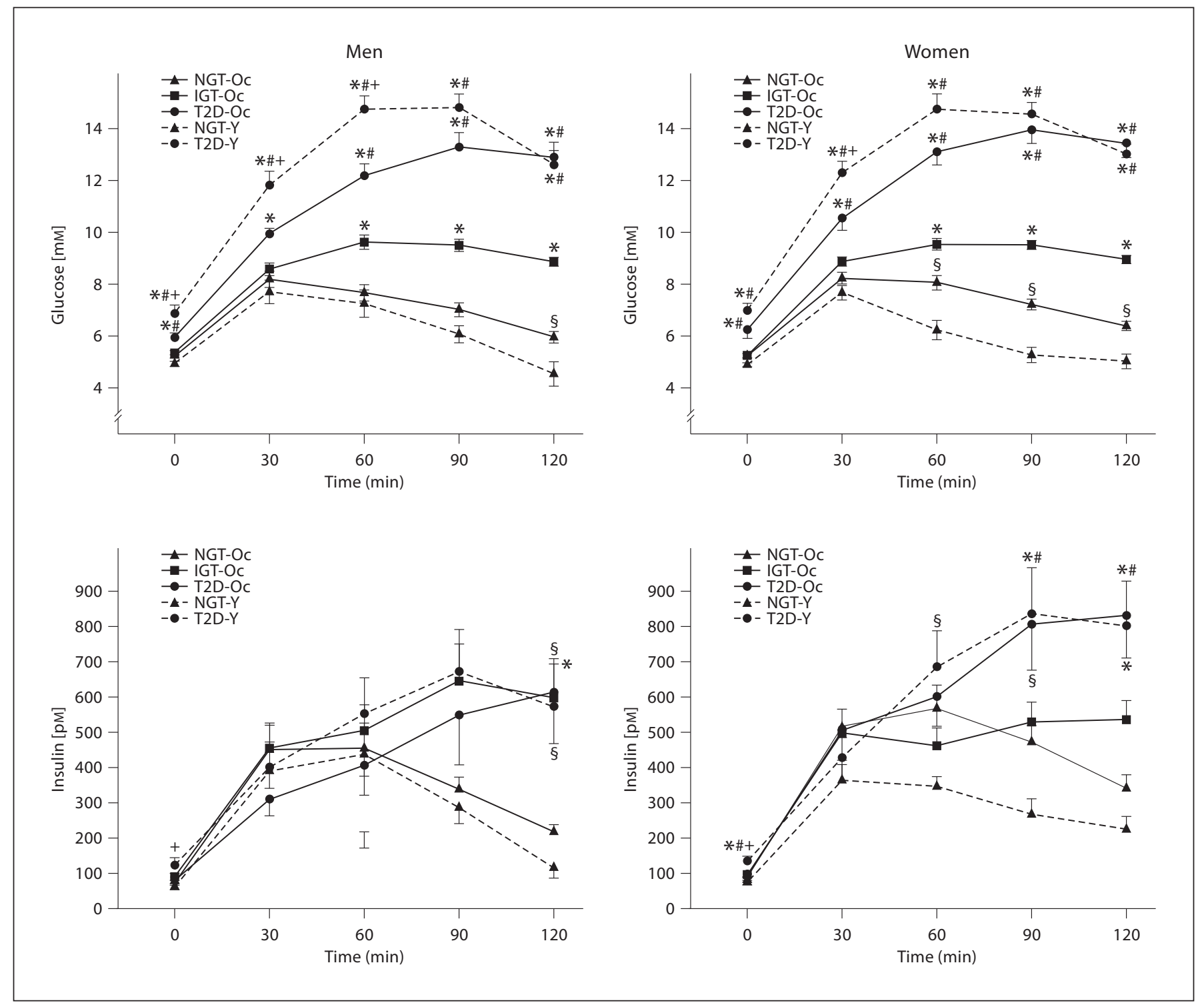

Fig. 1. Time course of plasma glucose and insulin in male and female octogenarians with NGT (NGT-Oc), IGT (IGT-Oc), type 2 diabetes (T2D-Oc) and corresponding middle-aged (younger) control groups with NGT (NGT$\mathrm{Y}$ ) and type 2 diabetes (T2D-Y) after standard OGTT. ${ }^{*} \mathrm{p} \leq 0.05 \mathrm{vs}$. NGT-Y and NGT-Oc ; ${ }^{*} \mathrm{p} \leq 0.05 \mathrm{vs}$. IGTOc; ${ }^{\S} \mathrm{p} \leq 0.05$ vs. NGT-Y; ${ }^{+} \mathrm{p} \leq 0.05$ vs. T2D-Oc.

adiponectin. Therefore, no differences have been found for total adiponectin between male normoglycemic octogenarians and octogenarians with T2D.

Based on the observation that LMW adiponectin was lower in male as well as in female octogenarians with $\mathrm{T} 2 \mathrm{D}$, a multivariate analysis was performed in a dataset stratified by sex with all observation groups (octogenarians and middle-aged controls) and both sexes (table 4). The data were adjusted for sex, age, and BMI by using these parameters as covariates. Generally, the resulting multivariate model indicated a significant effect of all observation groups on serum adiponectin levels (LawleyHotellings's trace: $\mathrm{p}=0.047$ ). The subsequent univariate multi-range analysis with $\mathrm{p}$ values corrected for multiple tests (Bonferroni procedure) confirmed significantly lower levels of LMW adiponectin in octogenarians with T2D in comparison to NGT octogenarians and octogenarians with IGT (table 4). 
Table 3. Fasting serum levels of total adiponectin and adiponectin isoforms in NGT-Oc, IGT-Oc, T2D-Oc, NGT-Y and T2D-Y

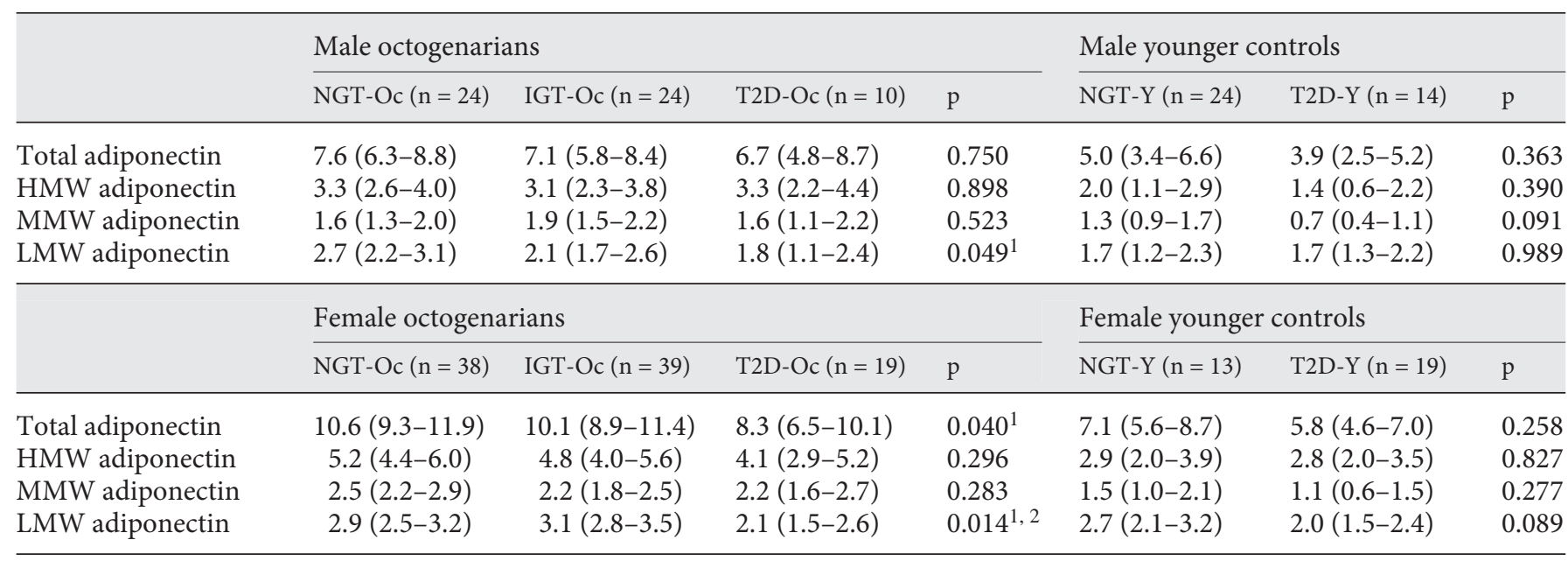

Data are presented as means $[\mu \mathrm{g} / \mathrm{ml}]$ with $95 \%$ confidence interval; differences analyzed by ANCOVA with data adjusted for age and BMI; Bonferroni test $\mathrm{p} \leq 0.05:{ }^{1} \mathrm{~T} 2 \mathrm{D}-\mathrm{Oc}$ vs. NGT-Oc; ${ }^{2} \mathrm{~T} 2 \mathrm{D}-\mathrm{Oc}$ vs. IGT-Oc.

Table 4. Results of a multivariate analysis of variance of the whole study population with age, sex, and BMI as covariates (effect of groups in the multivariate model: $\mathrm{p}=0.047$ by Lawley-Hotelling's trace)

\begin{tabular}{|c|c|c|c|c|c|c|c|}
\hline & \multicolumn{5}{|l|}{ Groups } & \multirow{2}{*}{$\begin{array}{l}\text { Univariate } \\
\text { analysis }\end{array}$} & \multirow{2}{*}{$\begin{array}{l}\text { Post-hoc analysi } \\
\text { with Bonferroni } \\
\text { correction } \\
\mathrm{p}\end{array}$} \\
\hline & $\begin{array}{l}\text { NGT-Oc } \\
(\mathrm{n}=62)\end{array}$ & $\begin{array}{l}\text { IGT-Oc } \\
(\mathrm{n}=63)\end{array}$ & $\begin{array}{l}\text { T2D-Oc } \\
(\mathrm{n}=29)\end{array}$ & $\begin{array}{l}\text { NGT-Y } \\
(\mathrm{n}=24)\end{array}$ & $\begin{array}{l}\text { T2D-Y } \\
(\mathrm{n}=33)\end{array}$ & & \\
\hline HMW adiponectin & $3.9(3.2-4.6)$ & $3.7(3.0-4.4)$ & $3.3(2.4-4.2)$ & $3.9(2.0-5.8)$ & $3.5(2.2-4.7)$ & 0.626 & n.s. \\
\hline MMW adiponectin & $1.9(1.6-2.2)$ & $1.8(1.4-2.1)$ & $1.7(1.2-2.1)$ & $2.2(1.3-3.1)$ & $1.7(1.1-2.3)$ & 0.402 & n.s. \\
\hline LMW adiponectin & $2.6(2.2-2.9)$ & $2.6(2.2-3.0)$ & $1.8(1.3-2.2)$ & $2.7(1.8-3.7)$ & $2.3(1.7-3.0)$ & 0.002 & $0.003^{1}$ \\
\hline
\end{tabular}

Data are presented as means $[\mu \mathrm{g} / \mathrm{ml}]$ with $95 \%$ confidence interval adjusted for age, sex and BMI; Bonferroni test: ${ }^{1}$ T2D-Oc vs. NGT-Oc and IGT-Oc.

Serum concentrations of total adiponectin and all adiponectin isoforms of male and female octogenarians with IGT were not statistically different from those of NGT octogenarians (table 3).

\section{Correlation Analyses of Adiponectin with Clinical \\ Data in Octogenarians}

The results of the partial correlation analyses with data controlled for BMI are shown in online supplementary table D. An exceptionally high direct correlation of total adiponectin and all adiponectin multimer complexes with HDL cholesterol was found in both men and women. On the other hand, hip circumference was in- versely correlated with total, HMW, and MMW adiponectin in men and women, and with LMW adiponectin in women only. Triglyceride levels revealed an inverse correlation with total, HMW, and MMW adiponectin and a direct correlation with the LMW/total adiponectin ratio in women.

Interestingly, LMW adiponectin, in contrast to HMW and MMW adiponectin, revealed a strong inverse correlation with fasting and 2-hour postchallenge glucose concentration in men and with 2-hour postchallenge glucose in women. Furthermore, the insulin levels $2 \mathrm{~h}$ after glucose load were inversely correlated with all adiponectin multimer isoforms in women. 


\section{Discussion}

Aging is associated with an increased risk of insulin resistance and diabetes mellitus. The current study on a clinically well-characterized population of octogenarians with different insulin sensitivity demonstrates selectively lower serum LMW adiponectin in male and female octogenarians with T2D. Serum levels of LMW adiponectin were reversely correlated with plasma glucose level $2 \mathrm{~h}$ after oral glucose challenge. A tendency of lower LMW adiponectin has also been found in a middle-aged group of female individuals with T2D, but not in a corresponding middle-aged male group.

Serum levels of total adiponectin and its isoforms are known to be affected by aging [24, 25], sex [24-26], and insulin sensitivity status [24-26]. In accordance with earlier studies describing increased total adiponectin with age $[24,25]$, the present study revealed higher levels of total adiponectin and adiponectin isoforms in normoglycemic octogenarians of both genders. The age-dependent increase in total adiponectin was slightly more pronounced in men (77\%) than in women (54\%). While in men this increase was primarily due to the increase of HMW and LMW adiponectin, in women the increase of total adiponectin was mainly induced by the elevation of HMW and MMW adiponectin. As a result, the HMW/ total adiponectin ratio increased in normoglycemic octogenarian men from 36.7 to $41.7 \%$ and in women from 43.1 to $47.5 \%$, when compared with normoglycemic middleaged individuals. Concurrently, the LMW/total adiponectin ratio decreased in normoglycemic octogenarian men from 39.1 to $31.1 \%$ and in women from 36.7 to $27.8 \%$ in comparison to middle-aged controls.

Although an increase in adiponectin levels with age has been reported by several studies [24, 25], the mechanisms for an age-related adiponectin increase are not fully understood. The effect of aging has been partially attributed to the reduction in the inhibitory effect of testosterone on adiponectin production with age. Notably, neither castration nor testosterone treatment modified the transcription activity of the adiponectin gene in adipocytes, suggesting that the regulation occurs at a posttranscriptional level [26]. Recent studies have demonstrated that the secretion of HMW adiponectin from adipocytes is much slower than that of LMW and MMW oligomer complexes, and that testosterone treatment leads to a further decrease in HMW adiponectin secretion [27]. These data suggest that different oligomeric complexes of adiponectin are released from adipocytes through at least two distinct secretory pathways [27].
Based on this, testosterone may selectively interfere with the HMW-specific mechanism of adiponectin secretion from the adipocyte. In line with this hypothesis, a more pronounced increase in HMW adiponectin in normoglycemic octogenarians could be explained in part by a selectively reduced inhibition of the testosterone-sensitive HMW secretory pathway. Very recently, an effect of female sex steroids on adiponectin oligomeric distribution in women has also been described [28]. While total, HMW, and MMW adiponectin was negatively associated with estradiol and progesterone, no association was observed for LMW adiponectin [28]. It is noteworthy that increasing concentrations of testosterone or estradiol influenced neither mRNA or protein expression nor adiponectin oligomer secretion in cultured preadipocytes [29].

Based on a differential hormonal background, sexual dimorphism in total, HMW, and MMW adiponectin has been reported in several studies on younger individuals [10, 11]. In extension of these data, the present study demonstrated gender differences also in octogenarians, in whom the hormonal background is expected to be more balanced. Women revealed significantly higher values for total, HMW, MMW, but not for LMW adiponectin. This observation is in accordance with Ebinuma et al. [11] who described the lack of gender difference for LMW adiponectin in a younger population, thereby supporting the hypothesis that, in contrast to higher molecular multimer complexes, sexual hormones might be less involved in the regulation of LMW adiponectin biosynthesis and secretion.

A growing number of studies indicate that the oligomer distribution of adiponectin is of greater relevance for its insulin-sensitizing activity than the plasma adiponectin concentration in total $[7,9,30]$. Earlier studies emphasized the importance of HMW adiponectin for the prediction and modulation of insulin resistance $[12,14]$. The reduction in insulin sensitivity in patients with T2D was accompanied by a decline in HMW adiponectin accounting for the total adiponectin reduction [31]. Moreover, recent data demonstrated that the HMW/total adiponectin ratio was independent of total adiponectin related to the risk of T2D [14, 32] and coronary artery disease [10, 33]. Although the insulin-sensitizing properties of adiponectin have been mainly attributed to HMW adiponectin and the HMW/total adiponectin ratio [30], Fruebis et al. [6] demonstrated that different oligomers of adiponectin activated different signaling pathways in myotubes and isolated rat muscles. LMW adiponectin, but not the HMW isoform, induced phosphorylation of the AMPK $\alpha$ subunit and thereby its activation in myotubes and isolated rat muscles. In addition, the trimeric globular head of adipo- 
nectin showed a much higher binding affinity than fulllength adiponectin to Adiporl, the predominant form of adiponectin receptor expressed in skeletal muscle [34]. On the basis of these findings, it was supposed that the trimer is the most potent isoform mediating beneficial metabolic effects of adiponectin in skeletal muscle.

Interestingly, the present study demonstrated significantly lower serum LMW adiponectin in male and female octogenarians with T2D compared to normoglycemic octogenarians. In men with $\mathrm{T} 2 \mathrm{D}$, this situation resulted from a lack of age-induced LMW adiponectin increase, which was characteristic of normoglycemic men. In women, already middle-aged individuals with T2D exhibited a strong tendency for lower LMW adiponectin. This tendency was enhanced in octogenarian women with T2D. The pathogenetic mechanisms behind these changes are unknown. An interaction between hormonal shifts and the development of insulin resistance should be taken into consideration. One important point to consider is the specific metabolic situation of the investigated population of octogenarians. Clearly categorized by OGTT in terms of blood glucose and corresponding insulin curves, male and female octogenarians with T2D did not differ from octogenarians with NGT in BMI, WHR, blood pressure, HDL and total cholesterol. In accordance with earlier publications [35-38], the data of the present study revealed a highly significant direct correlation of all adiponectin multimer isoforms with HDL cholesterol in men as well as in women. Therefore, it was not surprising that the missing difference in HDL cholesterol between T2D octogenarians and the corresponding NGT group was accompanied by an absence of significant differences in HMW and MMW adiponectin. The nature of the close association between adiponectin and HDL cholesterol is not fully understood. However, in a rat model an increase in HDL cholesterol and a decrease in triglycerides were induced through the permanent activation of the AMPK pathway by an adenosine analogue [39]. This points, at least in part, to a direct effect of adiponectin on HDL metabolism.

The contribution of a selective decline in LMW adiponectin in octogenarians with T2D to the pathophysiology of diabetes has not been completely elucidated. Besides its peripheral action, adiponectin plays a significant role in the central regulation of food intake and energy expenditure. Very recently, Coope et al. [18] demonstrated in rats that intracerebroventricular infusion of adiponectin induced an anorexigenic effect that was mediated through hypothalamic AdipoR1 receptors. Notably, in both humans and rodents, only the trimeric and hexameric complexes of adiponectin are present in cerebrospinal fluid
$[20,21]$. The HMW oligomeric adiponectin is virtually undetectable in cerebrospinal fluid, perhaps due to the extremely large size of this complex $(>500 \mathrm{kDa})$, which makes it difficult to translocate across the blood-brain barrier. Thus, the reduction in LMW adiponectin may be involved in a decline in insulin sensitivity in skeletal muscle and the central disinhibition of food intake promoting insulin resistance and obesity.

The increase in plasma adiponectin with age in normoglycemic individuals raised the question whether adiponectin might be a marker for longevity. This idea has been supported by recent studies showing an association of lower adiponectin levels with early onset and severity of coronary artery disease [40-42]. Low plasma levels of adiponectin were independently associated with increased intraventricular septum thickness, posterior ventricular wall thickness, and left ventricular mass index [43]. At the same time, evidence accumulates that increased adiponectin levels were closely associated with not only allcause mortality but also coronary heart disease (CHD) mortality in either sex [44-46]. This association seems to be particularly strong in the elderly and in patients at high risk for CHD. A prospective study on more than 4,000 elderly men aged 60-79 confirmed the results of previous studies showing that high adiponectin levels were associated with significantly increased mortality in elderly patients with CHD [46]. Despite the rapidly accumulating literature, it is still uncertain whether adiponectin levels have any clinical significance for risk stratification in cardiovascular disease and aging or whether they just reflect the activation of complex and opposing underlying mechanisms. Therefore, the role of adiponectin as a marker for longevity should be discussed with caution.

In conclusion, the present study demonstrates significantly lower levels of plasma LMW adiponectin in male and female octogenarians with T2D in comparison to octogenarians with NGT, probably as a result of the interaction of aging and insulin resistance. At the same time, serum levels of HMW and MMW adiponectin isoforms were not significantly different. The pathophysiological importance of reduced serum LMW adiponectin in individuals with higher age and increased insulin resistance remains to be established.

\section{Acknowledgements}

We thank Sigrid Nitzsche, Uta Buro, Bärbel Zeiler, Beate Kindel, and Simone Sperber for their excellent technical support, and Graham and Kathy Eisenhofer for a critical reading of the manuscript. 


\section{References}

1 Barbieri M, Rizzo MR, Manzella D, Paolisso G: Age-related insulin resistance: is it an obligatory finding? The lesson from healthy centenarians. Diabetes Metab Res Rev 2001; 17:19-26.

2 Combs TP, Berg AH, Obici S, Scherer PE, Rossetti L: Endogenous glucose production is inhibited by the adipose-derived protein Acrp30. J Clin Invest 2001;108:1875-1881.

3 Okamoto Y, Arita Y, Nishida M, Muraguchi M, Ouchi N, Takahashi M, Igura T, Inui Y, Kihara S, Nakamura T, Yamashita S, Miyagawa J, Funahashi T, Matsuzawa Y: An adipocyte-derived plasma protein, adiponectin, adheres to injured vascular walls. Horm Metab Res 2000;32:47-50.

4 Tsunekawa T, Hayashi T, Suzuki Y, MatsuiHirai H, Kano H, Fukatsu A, Nomura N, Miyazaki A, Iguchi A: Plasma adiponectin plays an important role in improving insulin resistance with glimepiride in elderly type 2 diabetic subjects. Diabetes Care 2003;26:285289.

5 Yamauchi T, Kamon J, Minokoshi Y, Ito Y, Waki H, Uchida S, Yamashita S, Noda M, Kita S, Ueki K, Eto K, Akanuma Y, Froguel P, Foufelle F, Ferre P, Carling D, Kimura S, Nagai R, Kahn BB, Kadowaki T: Adiponectin stimulates glucose utilization and fatty-acid oxidation by activating AMP-activated protein kinase. Nat Med 2002;8:1288-1295.

6 Fruebis J, Tsao TS, Javorschi S, Ebbets-Reed D, Erickson MR, Yen FT, Bihain BE, Lodish HF: Proteolytic cleavage product of $30-\mathrm{kDa}$ adipocyte complement-related protein increases fatty acid oxidation in muscle and causes weight loss in mice. Proc Natl Acad Sci USA 2001;98:2005-2010.

7 Pajvani UB, Hawkins M, Combs TP, Rajala MW, Doebber T, Berger JP, Wagner JA, Wu M, Knopps A, Xiang AH, Utzschneider KM, Kahn SE, Olefsky JM, Buchanan TA, Scherer PE: Complex distribution, not absolute amount of adiponectin, correlates with thiazolidinedione-mediated improvement in insulin sensitivity. J Biol Chem 2004;279: 12152-12162.

8 Tsao TS, Murrey HE, Hug C, Lee DH, Lodish HF: Oligomerization state-dependent activation of NF-kappa B signaling pathway by adipocyte complement-related protein of 30 kDa (Acrp30). J Biol Chem 2002;277:2935929362.

9 Waki H, Yamauchi T, Kamon J, Ito Y, Uchida S, Kita S, Hara K, Hada Y, Vasseur F, Froguel P, Kimura S, Nagai R, Kadowaki T: Impaired multimerization of human adiponectin mutants associated with diabetes. Molecular structure and multimer formation of adiponectin. J Biol Chem 2003;278:40352-40363.
10 Aso Y, Yamamoto R, Wakabayashi S, Uchida T, Takayanagi K, Takebayashi K, Okuno T, Inoue $\mathrm{T}$, Node $\mathrm{K}$, Tobe $\mathrm{T}$, Inukai T, Nakano Y: Comparison of serum high-molecular weight (HMW) adiponectin with total adiponectin concentrations in type 2 diabetic patients with coronary artery disease using a novel enzyme-linked immunosorbent assay to detect HMW adiponectin. Diabetes 2006; 55:1954-1960.

11 Ebinuma H, Miyazaki O, Yago H, Hara K, Yamauchi T, Kadowaki T: A novel ELISA system for selective measurement of human adiponectin multimers by using proteases. Clin Chim Acta 2006;372:47-53.

12 Hara K, Horikoshi M, Yamauchi T, Yago H, Miyazaki O, Ebinuma H, Imai Y, Nagai R, Kadowaki T: Measurement of the high-molecular weight form of adiponectin in plasma is useful for the prediction of insulin resistance and metabolic syndrome. Diabetes Care 2006;29:1357-1362.

13 Kobayashi H, Ouchi N, Kihara S, Walsh K, Kumada M, Abe Y, Funahashi T, Matsuzawa Y: Selective suppression of endothelial cell apoptosis by the high molecular weight form of adiponectin. Circ Res 2004;94:e27-e31.

14 Seino Y, Hirose H, Saito I, Itoh H: High molecular weight multimer form of adiponectin as a useful marker to evaluate insulin resistance and metabolic syndrome in Japanese men. Metabolism 2007;56:1493-1499.

15 Schober F, Neumeier M, Weigert J, Wurm S, Wanninger J, Schaffler A, Dada A, Liebisch G, Schmitz G, Aslanidis C, Buechler C: Low molecular weight adiponectin negatively correlates with the waist circumference and monocytic IL-6 release. Biochem Biophys Res Commun 2007;361:968-973.

16 Menzaghi C, Salvemini L, Paroni G, De Bonis C, Mangiacotti D, Fini G, Doria A, Di Paola R, Trischitta V: Circulating high molecular weight adiponectin isoform is heritable and shares a common genetic background with insulin resistance in nondiabetic White Caucasians from Italy: evidence from a family-based study. J Intern Med 2009;267:287-294.

17 Neumeier M, Weigert J, Schaffler A, Wehrwein G, Muller-Ladner U, Scholmerich J, Wrede C, Buechler C: Different effects of adiponectin isoforms in human monocytic cells. J Leukoc Biol 2006;79:803-808.

18 Coope A, Milanski M, Araujo EP, Tambascia M, Saad MJ, Geloneze B, Velloso LA: AdipoR1 mediates the anorexigenic and insulin/ leptin-like actions of adiponectin in the hypothalamus. FEBS Lett 2008;582:1471-1476.

19 Qi Y, Takahashi N, Hileman SM, Patel HR, Berg AH, Pajvani UB, Scherer PE, Ahima RS: Adiponectin acts in the brain to decrease body weight. Nat Med 2004;10:524-529.
20 Ebinuma H, Miida T, Yamauchi T, Hada Y, Hara K, Kubota N, Kadowaki T: Improved ELISA for selective measurement of adiponectin multimers and identification of adiponectin in human cerebrospinal fluid. Clin Chem 2007;53:1541-1544.

21 Kusminski CM, McTernan PG, Schraw T, Kos K, O’Hare J P, Ahima R, Kumar S, Scherer $\mathrm{PE}$ : Adiponectin complexes in human cerebrospinal fluid: distinct complex distribution from serum. Diabetologia 2007;50: 634-642.

22 World Health Organization: Definition, Diagnosis and Classification of Diabetes Mellitus and Its Complications. Report of a WHO Consultation. Part 1, Diagnosis and Classification of Diabetes Mellitus. Geneva, World Health Organization, 1999.

23 Matthews DR, Hosker JP, Rudenski AS, Naylor BA, Treacher DF, Turner RC: Homeostasis model assessment: insulin resistance and beta-cell function from fasting plasma glucose and insulin concentrations in man. Diabetologia 1985;28:412-419.

24 Adamczak M, Rzepka E, Chudek J, Wiecek A: Ageing and plasma adiponectin concentration in apparently healthy males and females. Clin Endocrinol (Oxf) 2005;62:114118.

25 Isobe T, Saitoh S, Takagi S, Takeuchi H, Chiba Y, Katoh N, Shimamoto K: Influence of gender, age and renal function on plasma adiponectin level: the Tanno and Sobetsu study. Eur J Endocrinol 2005;153:91-98.

26 Combs TP, Berg AH, Rajala MW, Klebanov $\mathrm{S}$, Iyengar $\mathrm{P}$, Jimenez-Chillaron JC, Patti ME, Klein SL, Weinstein RS, Scherer PE: Sexual differentiation, pregnancy, calorie restriction, and aging affect the adipocyte-specific secretory protein adiponectin. Diabetes 2003;52:268-276.

27 Xu A, Chan KW, Hoo RL, Wang Y, Tan KC, Zhang J, Chen B, Lam MC, Tse C, Cooper GJ, Lam KS: Testosterone selectively reduces the high molecular weight form of adiponectin by inhibiting its secretion from adipocytes. J Biol Chem 2005;280:18073-18080.

28 Leung KC, Xu A, Craig ME, Martin A, Lam KS, O'Sullivan AJ: Adiponectin isoform distribution in women - relationship to female sex steroids and insulin sensitivity. Metabolism 2009;58:239-245.

29 Horenburg S, Fischer-Posovszky P, Debatin $\mathrm{KM}$, Wabitsch M: Influence of sex hormones on adiponectin expression in human adipocytes. Horm Metab Res 2008;40:779-786.

30 Kaser S, Tatarczyk T, Stadlmayr A, Ciardi C, Ress C, Tschoner A, Sandhofer A, Paulweber B, Ebenbichler CF, Patsch JR: Effect of obesity and insulin sensitivity on adiponectin isoform distribution. Eur J Clin Invest 2008; 38:827-834. 
31 Nakashima R, Kamei N, Yamane K, Nakanishi S, Nakashima A, Kohno N: Decreased total and high molecular weight adiponectin are independent risk factors for the development of type 2 diabetes in Japanese-Americans. J Clin Endocrinol Metab 2006;91: 3873-3877.

32 Heidemann C, Sun Q, van Dam RM, Meigs JB, Zhang C, Tworoger SS, Mantzoros CS, Hu FB: Total and high-molecular-weight adiponectin and resistin in relation to the risk for type 2 diabetes in women. Ann Intern Med 2008;149:307-316.

33 von Eynatten M, Humpert PM, Bluemm A, Lepper PM, Hamann A, Allolio B, Nawroth PP, Bierhaus A, Dugi KA: High-molecular weight adiponectin is independently associated with the extent of coronary artery disease in men. Atherosclerosis 2008;199:123128.

34 Yamauchi T, Kamon J, Ito Y, Tsuchida A, Yokomizo T, Kita S, Sugiyama T, Miyagishi M, Hara K, Tsunoda M, Murakami K, Ohteki T, Uchida S, Takekawa S, Waki H, Tsuno NH, Shibata Y, Terauchi Y, Froguel P, Tobe K, Koyasu S, Taira K, Kitamura T, Shimizu T, Nagai R, Kadowaki T: Cloning of adiponectin receptors that mediate antidiabetic metabolic effects. Nature 2003;423:762-769.
35 Altinova AE, Toruner F, Bukan N, Yasar DG, Akturk M, Cakir N, Arslan M: Decreased plasma adiponectin is associated with insulin resistance and HDL cholesterol in overweight subjects. Endocr J 2007;54:221-226.

36 Zietz B, Herfarth H, Paul G, Ehling A, Muller-Ladner U, Scholmerich J, Schaffler A: Adiponectin represents an independent cardiovascular risk factor predicting serum HDL-cholesterol levels in type 2 diabetes. FEBS Lett 2003;545:103-104.

37 van Hoek M, van Tol A, van Vark-van der Zee LC, Jansen H, Kastelein JJ, Sijbrands EJ, Dallinga-Thie GM: Role of plasma adiponectin on the HDL-cholesterol raising effect of atorvastatin in patients with type 2 diabetes. Curr Med Res Opin 2009;25:93-101.

38 Lara-Castro C, Luo N, Wallace P, Klein RL, Garvey WT: Adiponectin multimeric complexes and the metabolic syndrome trait cluster. Diabetes 2006;55:249-259.

39 Buhl ES, Jessen N, Pold R, Ledet T, Flyvbjerg A, Pedersen SB, Pedersen O, Schmitz O, Lund S: Long-term AICAR administration reduces metabolic disturbances and lowers blood pressure in rats displaying features of the insulin resistance syndrome. Diabetes 2002;51:2199-2206.

40 Frystyk J, Berne C, Berglund L, Jensevik K, Flyvbjerg A, Zethelius B: Serum adiponectin is a predictor of coronary heart disease: a population-based 10 -year follow-up study in elderly men. J Clin Endocrinol Metab 2007; 92:571-576
41 Hara K, Yamauchi T, Imai Y, Manabe I, Nagai R, Kadowaki T: Reduced adiponectin level is associated with severity of coronary artery disease. Int Heart J 2007;48:149-153.

42 Hashimoto N, Kanda J, Nakamura T, Horie A, Kurosawa H, Hashimoto T, Sato K, Kushida S, Suzuki M, Yano S, Iwai R, Takahashi $\mathrm{H}$, Yoshida S: Association of hypoadiponectinemia in men with early onset of coronary heart disease and multiple coronary artery stenoses. Metabolism 2006;55:1653-1657.

43 Paakko T, Ukkola O, Ikaheimo M, Kesaniemi YA: Plasma adiponectin levels are associated with left ventricular hypertrophy in a random sample of middle-aged subjects. Ann Med 2010;42:131-137.

44 Dekker JM, Funahashi T, Nijpels G, Pilz S, Stehouwer CD, Snijder MB, Bouter LM, Matsuzawa Y, Shimomura I, Heine RJ: Prognostic value of adiponectin for cardiovascular disease and mortality. J Clin Endocrinol Metab 2008;93:1489-1496.

45 Poehls J, Wassel CL, Harris TB, Havel PJ, Swarbrick MM, Cummings SR, Newman AB, Satterfield S, Kanaya AM: Association of adiponectin with mortality in older adults: the Health, Aging, and Body Composition Study. Diabetologia 2009;52:591-595.

46 Wannamethee SG, Whincup PH, Lennon L, Sattar N: Circulating adiponectin levels and mortality in elderly men with and without cardiovascular disease and heart failure. Arch Intern Med 2007;167:1510-1517. 